\title{
Queering Postcolonial Travel Writing
}

\author{
Churnjeet Mahn
}

\section{Churnjeet.mahn@strath.ac.uk.}

School of Humanities, University of Strathclyde. Lord Hope Building, Glasgow G4 0LT.

Beginning with contemporary calls to decolonise travel writing, this article considers the intersection of race and sexuality in the genre. Why is the analysis of postcolonial travel writing so straight? Why is the analysis of queer travel writing so white? By answering these questions simultaneously, the article argues for the creation of a space from which we can understand how single-issue approaches to identity politics fail to take account of structural forms of homophobia and racism. Acknowledging their structural manifestations through the history of colonialism should advance an understanding of how and why some of the most historically queer-inclusive and diverse places in the world have come to be represented as the most hostile to queers in travel writing.

Keywords: Queer; LGBTQI; decolonial; postcolonial.

Queerness and travel have an intimate relationship that is being explored by a new generation of writers, activists, and artists, who are using the real and figurative borders that police race and sexuality to question again why writing about travel matters. More than this, they question how intimately our understanding of race and sexuality is entwined. The following from the travel writer and blogger Bani Amor is an indicative of a range of voices in the field: 
Consider the relative ease with which Western cis male tourists are able to travel. Travel writing, blogs, and memes overflow with entitled, thoughtless language like, "Spin the globe. Where it lands, that's where we'll go," and "I was not born for one corner; the whole world is my native land." They generally have more money to spend on travel, more time to take off from work, less responsibilities to family, powerful passports, and few barriers to acquiring visas and are not criminalized by the TSA, are less vulnerable to policing and sexual harassment, and besides not having to worry about being treated like a human being wherever they go, are treated like rock star royalty in the developing world, where their dollars triple. (Amor 2017)

Evolving technologies (such as biometrics) and surveillance (such as increasingly invasive searches) police the way in which bodies, especially sexualised and racialised ones, cross borders. What does it take to be a credible traveller, or a credible tourist? What spaces are accessible to you? When do you get stopped or called out? Twitter hashtags like \#airbnbwhileblack from 2018 demonstrate how the very technologies that are meant to make travel and tourism more inclusive and diverse, are so entrenched in white privilege, they cannot even imagine or mitigate the reality of racial profiling. If travel has democratised, access has not. And while racial difference has been an issue at the heart of travel writing since the inception of the genre and its study, its discussion is easily obfuscated when it comes up against sexuality. It is time to talk about race and racism in queer travel writing.

John Whittier Treat's, Great Mirrors Shattered (1999) charts the AIDS crisis in Japan and the lure of the Orient to the western scholar. Treat, an Emiritus Professor at Yale University with an expertise in modern Japanese literature, uses his travels to offer a powerful commentary on transnational gay desire after the AIDS crisis. His analysis of the Japanese reaction to AIDS and of how the narrative of gay mobility and disease itself 
travelled across continents offers a snapshot into how the homophobia generated by the AIDS crisis continued to generate new kinds of stigma, marginalisation and discrimination for gay men globally. Treat engages with the problematics of cross-cultural desire directly, here describing an encounter with a Filipino man in Japan:

As I stroked his hard thighs, he spoke with much confidence about the destruction of his country at the hands of its leaders; as I tried to arouse him a second time, he went on to remind me of what America had contributed to the tragedy that was, and is, the Philippines. We went back to the rug and screwed again, America fucking the Philippines once more with gusto, or so it must have appeared; but in fact it was two men who despite history, took temporary refuge for one moment in a mutual and voluntary desire. (Treat 1999, 45)

Treat's excursion into sensuality does not substantiate his concluding observation about equality, power, and reciprocity in this encounter. In fact, as his lover speaks "with much confidence" (which within it contains the implicit assumption that what he says may not be valid), Treat's focus is on how his lover's treatise on inequality and exploitation can become the narrative arc of the sexual encounter. The "so it must have appeared" is the tell of an ironic distancing gifted to Treat, but not his lover. He is aware of how this may look, of another rehearsal of "other" or exotic bodies becoming sites of consumption, but there is very little to underwrite the mutuality of this moment beyond the gesture of sincerity. For the critical study of queer travel writing to move towards a broader recognition that gets beyond the dated categories of "gay" and "lesbian", it is necessary to address the genre's whiteness. This is a process that requires an understanding of how the global movement for LGBTQ+ rights has been dominated by the Global North, which in turn has facilitated the categorisation of some of the world's most historically queer cultures (in the Middle East, and across Asia) as some of the most homophobic places on the planet. In terms of scholarly 
discussions of travel writing, there is a two-fold problem: the whiteness of queer travel writing, and the heteronormativity of postcolonial travel writing.

This article is an attempt to understand the potential for a new type of inquiry into travel writing that troubles the idea that the genre has become, and is becoming, more inclusive. It does not offer a detailed analysis of single travel texts; rather, it assembles a critical framework through which to read a diverse range of texts together in a new sub-genre. These are texts which normally are tagged under "LGBTQ rights", "Islam and sexuality", or area studies. For the purposes of this article, I am going to focus on the vast geographical expanse of the "Orient" as it provides a specific example of how homonormativity is written in and out of the legacy of travel writing. I propose that an area of inquiry we could call queer postcolonial travel writing offers a way to reinvigorate some of the existing debates in postcolonial travel writing, while challenging its profound heteronormativity. In this article I want to offer an overview of how and why queer travel writing by people of colour is making such a significant impact outside the field of travel writing, while being generally relegated to the margins within it. The study of queer travel writing often feels like a terminal point of conversation or analysis in travel writing: it is not well covered in anthologies, handbooks, or travel writing conferences. But I want to challenge that by thinking about the history of queer travel writing as one of the most productive and important routes into decolonising the history and practice of the genre.

Thinking about queer postcolonial travel writing involves examining the work of contemporary queer writers whose non-fiction accounts of travel interweave a globalised understanding of LGBTQ sexualities with anti-racist and decolonial politics. The following examples come from a range of work, not usually discussed together, which span the queer Oriental world. Michael Luongo's landmark edited collected, Gay Travels in the Muslim World (2007) features work by travellers, tourists, and men who live in the Muslim world, or 
have left it because of their sexuality. 9/11 haunts the work, but so does a particular mix of Oriental homo-desire which consistently objectifies black and brown men. In his study of the homosexuality and the Mediterranean, Robert Aldrich quotes a personal ad which offers the basic formula to many of these interactions: "'If you are Mediterranean, easygoing, fit, shortto-medium in height and would like to meet two, late-twenties, Anglo-Celtic guys who are fit and attractive, please write..."' (quoted in Aldrich 1993, ix). ${ }^{1}$ Sarah Schulman's Israel/Palestine and the Queer International (2012) travels to one of the most contested fringes of the Muslim world to situate a utopian politics: "I am a citizen of what I am thinking of as 'the queer international,' a play on history, words, and movements past and present" (Schulman 2012, 65). Self-consciously drawing on the work of Jasbir Puar and Judith Butler, Schulman uses queer feminist positionality to reconfigure the travel encounter as an act of witnessing and solidarity. ${ }^{2}$ Benjamin Law's Gaysia (2012) is a camp rewriting of Orientalist stereotypes: "Of all the continents, Asia is the gayest. Deep down, you've probably had your suspicions all along, and I'm here to tell you those suspicions are correct" (Law 2012, 1). His satirical configuration of Gaysia/queer Asia is understood through the weight of fact: the region with the world's largest population should be, empirically, the world's queerest place.

What connects these texts is a historical understanding of the existence (and the prominence) of queer cultures across the Middle East and Asia. A recurring narrative in this body of writing is the idea that gay rights belong to the Global North and everywhere else is incredibly homophobic. This often plays out between three competing interests: a local subject who has experienced homophobia, a misunderstood LGBTQ+-focused NGO trying to do the right thing, and a participant observer (the author) who attempts to provide an empathetic bridge to a local environment while distancing themselves through commenting on their own open/privileged queer lives. Here is an example of Law discussing his travel 
through India and his interview with activists attached to the Naz Foundation (a leading HIV and LGBTQ+ charity in India):

They met with a lot of resistance. Older queens in the park would tell the younger boys not to listen to Anjali. She had come from the West, they said, and was spreading false rumours about a disease that didn't exist. Some of them speculated that the real reason Anjali was there was that she, like Baba Ramdev, wanted to make them all straight. Anjali laughed thinking about it now but, looking back, realised she had been on a steep learning curve too.

"You're very clear in the states when you go through your training," she said. "People are either straight, bi or gay. Here, in India, there's like this whole other world. One had to relearn everything." (Law 2012, 251)

The inadequacy of mapping a sexual vocabulary that has its roots in English and other European languages comes into sharp focus when Anjali tries to work with members of the third sex in India, such as hijras, for whom even the term "transgender" is a controversial appellation. With money for public health and advocacy for sexual minorities, alongside their recognition on a global scale being predominantly resourced by the Global North, what does it mean to be an Oriental queer - a figure so common in cultural representation and travel narratives, but rendered so invisible by a global LGBTQ+ agenda, which sees people like hijras as benefactors of queer liberation in the US, or Europe. This jarring moment, this "whole other world" and its encounter with the queer world we think we know in travel writing, is my focus.

This following discussion offers an overview of the disciplinary developments and entanglements in the study of travel writing, queer theory and postcolonial studies in order to understand the distance between mainstream studies of travel writing (especially on the topic of race), and sexuality. What would a sub-field of queer postcolonial travel look like? 
Metaphors of travel and critiques of mobility find themselves on heavy rotation in studies of queer life, with Jay Prosser's 1999 comment, "Border crossing has become the trope for the end of our millennium" (Prosser 1999, 83) now requiring an indefinite extension. Despite the recurring interest in mobility in queer theory, there is remarkably little scholarship on queer travel writing (Mahn 2015). And while queer postcolonial studies, especially in literature and history has been energised by a generation of scholars who have queered postcolonial theory and used postcolonial theory to challenge the whiteness of queer studies, ${ }^{3}$ in the midst of this intellectual traffic, the study of travel writing has largely failed to produce a sustained engagement with queer theory. What makes this strange, and why the queer postcolonial has a particular resonance for travel writing, can be found in the source material used for historicised studies of queer life, especially around the Mediterranean, the Middle East and Asia, which frequently (re)turns to travel writing as an invaluable medium for understanding the way real encounters with sexual and racial "others" are conditioned by sexualised stereotypes and how travel accounts can provide evidentiary fodder for the perpetuation of those stereotypes. Recent studies of LGBTQ tourism underscore how the development and evolution of the global LGBTQ tourism industry is driven by and is predominantly for male middle-class travellers and tourists from the Global North.

Queer postcolonial travel writing can create a space for the examination of the nonfiction work of contemporary queer writers who use their personalised accounts of travel and tourism in the Middle East, across the Muslim world, and in Asia, to variously reinforce or challenge the Global North's perceived monopoly on "progressive" LGBTQ rights through activating dialogues between localised histories of (non-)heteronormative lives and practice with the contemporary politics of global, or universal, LGBTQ rights. This is a discussion which seeks to disaggregate some of the layered assumptions and histories which constitute non-white queer bodies in contemporary travel writing through using a longer view of 
homoeroticism's central importance in Orientalism and empire to ask why, and how, some of the most sexually "permissive" and progressive places in the world have come to be represented as some of the most homophobic and repressive to queers. How have Morocco, Afghanistan or India changed from being some of the queerest of places for travellers in the nineteenth and early twentieth century, to some of the most dangerous for same-sex encounters? While the geographical areas referenced in this article are not exclusively Muslim (Israel/Palestine, North Africa, the Middle East and South and South East Asia), the spectre of Orientalism and reality of contemporary Islamaphobia is a recurring theme that seeps into the characterisation of non-Western queer sexualities, namely, that they are prone to more extreme state-sponsored and cultural homophobia.

Queer accounts of travel do not have a natural or obvious place in the Travel Writing section of real or virtual bookshops, partially due to the perception of a diminishing interest in the genre as a whole. Contemporary travel writing, just like the novel, is constantly faced with the redundancy of its form. In Granta magazine's 2017 series “Is Travel Writing Dead?" novelists, self-proclaimed travel writers, and non-fiction writers came together to provide responses to the question (to which the answer was "no"). For the Pakistani novelist Mohsin Hamid, travel writing is not a simply a non-fiction genre, but a way of understanding the experience and condition of mobility in writing: "It sometimes seems to me that all my writing is travel writing. Perhaps this is because I have moved so much in my life: most of my first decade was spent in California, my second in Lahore, my third in New York, my fourth in London, and my fifth, thus far, in Lahore again" (Hamid 2017). For the self-styled global citizen and travel writer Pico Iyer, travel writing is far from dead: "If anything, it's broken out of its self-created shell, as more and more women give us their half of the world, and Paris is ever more crowded with visitors from Chengdu" (Iyer 2017). What marks 
contemporary travel writing apart from an earlier phase of writing so dominated by the colonial encounter is a distinct and destructive interest in old maps. ${ }^{4}$

The era of the (appearing straight but often queer) white European man on the road, reporting the world, may be over, but the problem for the genre is that finding what counts as travel writing requires an expansive approach that needs new maps. In her discussion of the map as metaphor in postmodern writing, Peta Mitchell traces a shift from the Enlightenment map metaphor as representing an all-encompassing or total representation of knowledge, to its more contemporary use: "In a world in which the real is no longer a given, the map becomes a key metaphor for the negotiation (physical and cognitive) required in order to derive meaning from our environment" (Mitchell 2008, 3). Map metaphors have moved to mapping metaphors which are informed by questions of perspective and distance. They are common currency in writing about travel: for instance, "To a certain extent, however, travel writing is inevitably one-way traffic, because Europeans mapped the world rather than the world mapping them' (Clark 1999, 3); or Graham Greene’s Journeys without Maps ([1936) which describes a blank space on a map marked "Cannibals" as a prompting desire for travel (the "blank" area is Liberia). In a discussion of the prevalence of travel in transgender narratives, Aren Aizura asks: "What different accounts might we arrive at by deconstructing the travel metaphor's historical, geographical, and racially specific logics rather than understanding the travel metaphor as impelled by individual autobiographies?" (Aizura 2018, 34). Questioning what impels map-making, real and imaginary, has become the paradigmatic shift in studies of travel writing from the past thirty years, with a particular emphasis on the postcolonial and the global, but extremely rarely about the queer. ${ }^{5}$ Queer travel writing has been overwhelmingly dominated by the experience of white middle-class men.

The walls around this study are papered with three competing attempts to construct transnational geographies of queer sex(ualities). The first is Richard Burton's imaginary map 
of Pederasty from 1885. As an Orientalist par excellence, Burton's map in this study represents the co-ordinated efforts of travellers, from classicists and anthropologists, to colonial officials and scientists, to offer a taxonomy of sexual perversity that interlaced racism and homophobia. The second map is a series produced by the International Lesbian and Gay Association (ILGA) documenting the change in sexual orientation laws across the world. This is a map which various government websites reference to advise on safety for LGBTQ citizens who may be travellers or tourists. Replicating the rights of heteronormative citizens (especially marriage equality) becomes the barometer for the quality of queer life. While some legislatures have laws explicitly forbidding same-sex contact (often hangovers of colonial law), the lack of explicit recognition of queer rights becomes the canary in the mine. The third map, Queering the Map, is:

a community-generated mapping project that geo-locates queer moments, memories and histories in relation to physical space. As queer life becomes increasingly less centred on specific neighbourhoods and the buildings within them, notions of "queer space" become more abstract and less tied to concrete geographical locations. (Queering the Map).

Queering the Map alludes to how the increasing mainstream acceptance of LGBTQ people in the Global North combined with the gentrification of LGBTQ spaces, particularly in Europe and North America, has led to their erasure (Schulman 2012; McLean 2018). Queering the Map invites participants to geo-locate their embodied feelings of queerness. ${ }^{6}$ While the map is most densely populated with content from North America and Europe, there are an increasing number of tags across the world, pinning queer feelings along with the feeling of place. ${ }^{7}$ The operation of Queering the Map that resonates in this work is the attempt to connect feelings of queer intimacy across the globe, to curate/create transperiphal solidarities that reads some kind of continuity between a first kiss in Delhi and falling in love in 
Montreal. This is not to erase the stark differences between the context of the encounters, or the histories and political currents that make the identification of queer identities and bodies possible. Rather, it is to speculate about the motivation to use creative methods that resist the consumer frameworks of tourism, or the political frameworks of global LGBTQ politics, to think queerly across borders. The rest of this article outlines the taxonomies that underpin these maps. It begins with the discussion of the recurring importance of Orientalism, especially in light of recent work, to read the importance of homoeroticism and homosexuality back into its history. It then touches on work in queer diaspora studies and geopolitical queer theory to decentre the Eurocentrism of queer theory, itself a challenge to the envisioning of "global queer" rights or subjects.

The Orientalist and traveller Richard Burton's “Terminal Essay", published as part of the translation of Arabian Nights in 1885, undertakes a tentative queer cartography in a section on "Pederasty". Identifying the most appropriate co-ordinates and climates for samesex contact, his "Sotadic Zone" is a geographical stretch that runs from the northern Mediterranean (N. Lat, 43 degrees) to its southern shore (N. Lat, 30 degrees). ${ }^{8}$ The resulting corridor, which encapsulates Italy, Greece, Morocco and Egypt, runs eastward through the Levant, narrowing around Asia Minor (Afghanistan, Sind and Punjab are included, but not the southern states of India), only to expand to encapsulate most of Asia. Running along the contours of his imaginary map, Burton argues for a topographical approach which uses "geographical and climatic, not racial" factors to explain deviation in normative sexual practices. Navigating the British censor with his own personal and intellectual interests in homosexuality, Burton's tone has degrees of knowing that invite the right kind of audience to read against the grain: "Within the Sotadic Zone the Vice is popular and endemic, held at the worst to be a mere peccadillo, whilst the races to the North and South of the limits here defined practise it only sporadically amid the opprobrium of their fellows who, as a rule, are 
physically incapable of performing the operation and look upon it with the liveliest disgust" (Burton 1886, 177). Travelling through discussions of "Greek love”, Orientalism, and observations on sexual customs across the world, Burton describes a (distinctly non-Northern European) queer world with historical depth, diversity and massive geographical expanse. It is hard to think of a better advertisement for some of Burton's fellow British travellers (particularly men) for whom more temperate climates could yield sexual lives and encounters rendered dangerous or impossible by legislation and attitudes in the UK.

For travel writing, tracing both the central importance of homoeroticism to Orientalism and Orientalism's afterlives in more contemporary travel writing have often gone as unconnected enterprises. Joseph Allen Boone's The Homoerotics of Orientalism (2015) has provided an exemplary queer corrective to Edward Said's Orientalism (1978), demonstrating the extent to which fantasy-driven representations of Oriental queers permeated the Western imagination, despite the overwhelming heterosexism of Said's original project. ${ }^{9}$ Boone's work is in some ways a counterpart to Meyda Yeğenğolu's (1998) work on feminism and Orientalism and Reina Lewis's (2004) work on women travellers and Orientalism, and part of a larger continuing critique of Said's work which points to the temptation to read the Orient as a static and closed system, something acted upon rather than acting, while consistently returning to the revivification of his original text through new critical paradigms. A productive starting point for queering postcolonial travel writing is to group together contemporary queer-identified writers, loosely travelling in what would be identified as the Eurasian portion of Burton's Sotadic Zone, whose imaginary maps recontour the area covered by the Sotadic Zone into some of the most homophobic and impossible territories for queer life in the world.

This inquiry draws on the concerns of an emerging field at the intersection of area studies, postcolonial studies and queer theory that critiques the citational circuits which limit 
the critical and imaginative scope of queer theory. How well do the critical templates and assumptions produced by queer theory in the Global North work with, suit, or take account of the diversity of sexual difference across the globe? As Miskdashi and Puar have argued, "At the outset, the work of queer theorists in area studies (rarely read by queer theory as 'Queer Theory' and often relegated to 'sexuality studies') is understood as a 'case study' of specifics rather than an interruption of the canonical treatments of the area studies field at large" (Miskdashi and Puar 2016, 216). Disciplinary cleavages have conspired to edge out or marginalise knowledge about, primarily, queerness outside the experience of whiteness. For Arondekar, "geopolitical sites (particularly in the Global South) continue to be read as obdurately and enticingly unresponsive - literally ungraspable forms" (Arondekar 2016b, 333). The substantial archival and socio-cultural work of critics such as Anjali Arondekar (2016a) and Khaled El-Rouayheb (2005), have been part of a powerful effort to rewire the historical framework of queer studies and the historical understanding of the operation of gender and sexuality beyond simply adding case studies demonstrating difference. The rise of global NGOs to protect or advocate for queer people has been a by-product of a LGBTQ civil rights movement in the Global North that responded to repressive state and cultural apparatuses. The exporting of queer liberation or rights has not adequately dealt with, or engaged with, the histories of colonialisation and racism that produced homophobic legislation across parts of Africa and South and South East Asia. Gayatri Gopinath argues that models for global LGBTQ rights assume the "rewriting colonial constructions of 'Third World' sexualities as anterior, pre-modern, and in need of Western political developments constructions that are rearticulated by contemporary gay and lesbian transnational politics" (Gopinath 2005, 12).

The ILGA (International Lesbian, Gay, Bisexual, Trans and Intersex Association), an NGO which represents over a thousand international LGBTQI+ organisations, has been 
producing overview maps charting the national legal status of LGBTQI+ people across the world. ${ }^{10}$ The 2017 map showing the equal recognition of same-sex relationships and adoption rights is largely restricted to the Americas, Europe, South Africa and Australia (Israel and Taiwan are notable exceptions). In the 1999 preface to Gender Trouble, Judith Butler revises some of her earlier arguments, making room for a universal basis for sexual rights without the wholesale contradiction of her work on the very impossibility of universal categories. On the ethical potential of universality, she comments,

I came to see the term has important strategic use precisely as a non-substantial and open-ended category and I worked with an extraordinary group of activists first as a board member and then as board chair of the International Gay and Lesbian Human Rights Commission (1994-7), an organisation that represents sexual minorities on a broad range of human rights issues. There I came to understand how the assertion of universality can be proleptic and performative, conjuring a reality that does not yet exist, and holding out the possibility for a convergence of cultural horizons that have not yet met. (Butler [1999] 2010, xvii-xviii)

One of the most vocal and vociferous critics of global LGBTQ organisations, especially in the Middle and Near East, has been Joseph Massad: "Western male white-dominated organizations (The International Lesbian and Gay Association - ILGA - and the International Gay and Lesbian Human Rights Commission - IGHLRC) sprang up to defend the rights of 'gays and lesbian' all over the world and to advocate on her behalf $[\ldots]$ it is these missionary tasks, the discourse that produces them, and the organizations that represent them which constitute what I call the Gay International” (Massad 2007, 161). While Massad is right to highlight how some racist strategies within the operation of Orientalism have tracked across into scholarly work (used as cultural evidence or commentary) that has been used and cited by key LGBTQ NGOs, his own counter-proposal of what Muslim cultures have been or look like itself relies on pointing to another evidence base which disproves the existence of 
homosexuality as a meaningful category of existence or identification. As Aleardo

Zanghellini has argued, "homosexuality happens to be, for conceptual, demographic,

strategic, and historical reasons, a particularly suitable field on which to enact the context of identity politics" (Zanghellini 2009, 271).

Ruth Vanita (2002) and Naisargi N Dave (2012), in particular, have pointed to the power and relevance of reading queer subjects globally, especially as the legacies of colonialism and contemporary discourses around homosexuality across the world identify, marginalise and punish sexual minorities. Puar's work on the operation of homonationalism has been invaluable for suturing the relationship between queers and the state (Duggan 1994) with an understanding of how racism operates to privilege the white homonormative subject. In Israel/Palestine, Schulman lists news stories to evidence this project:

In the Netherlands, 22 percent of readers of Gay Krant, a popular gay magazine, announced their support for Geert Wilders's anti-immigrant Party for Freedom. $[\ldots]$ In London, Safra Project, a queer Muslim organization, asked white gays to cancel a pride march in an immigrant neighbourhood partially because of its associations with the English Defense League, a Far Right group.

In Norway, Anders Behring Breivik, who killed scores of Muslim teenagers at a youth camp, cited American gay writer Bruce Bawer's anti-Muslim essays among his influences. (Schulman 2012, 104)

Schulman, through Puar, demonstrates how racism can be utilised as a tool to reinforce race as an axiom of difference that cannot be disrupted by, or undone by, queer alliances. ${ }^{11}$ This body of work sits uncomfortably with the work of Jeffrey Weeks and Gregory Woods, leading gay intellectuals for whom the successes of the LGBTQ movement in Europe can offer an up-scalable template for LGBTQ rights everywhere. 
Jeffrey Weeks, in The World We Have Won: The Remaking of Erotic and Intimate Lives (2007), argues that, "We are living [...] in a world of transition, in the midst of a long, convoluted, messy unfinished but profound revolution that has transformed the possibilities of living our sexual diversity and creating intimate lives" (Weeks 2007, 3). ${ }^{12}$ The transformation Weeks describes speaks to the gay travel writing of the 1990s and early 2000s which uses travel as a way of exploring the "messy" possibilities of gay life. The revolution in gay rights and visibility in North America and parts of Europe that Weeks alludes to does not necessarily correlate with a revolution in social attitudes about other cultures when it comes to travel. In other words, while the possibility of gay travel writing may be the consequence of a form of social "revolution", that revolution does not necessarily guarantee that the style or content of gay travel writing in this period is transgressive in its expression. Holland and Huggan argue, "now that homosexuality is no longer intrinsically transgressive in white cultures, gay travels has become a field in its own right, connected with guiding gay travellers to favourable locales rather than with recording trajectories of sexual play in more or less coded discourses" (Holland and Huggan 2000, 134). Somewhere in the balance between Weeks and Holland and Huggan is the precarious niche in which queer travel writing finds itself: its interest is often deemed to be the testimony or documentation of gay life, but the increasing recognition of gay lives in mainstream society in the Global North undermines its transgressive minority appeal. Instead, its transgressive appeal is relocated to places "dangerous" for queers, a route which inevitably leads to the activation of racist stereotypes about the homophonic Global South, and particularly Muslim cultures.

If postcolonial travel writing has been about decentring the importance of the European and North American gaze, then queering postcolonial travel writing is not only about decentring the experience of heteronormativity in the travel encounter, but also about questioning the project to normalise, or make recognisable, queer bodies across the world. 
Writers such as Michael Luongo, Bani Amor, and Benjamin Law, Sarah Schulman, and many others, are representatives of a new wave of queer postcolonial travel writing. They are all members of queer diasporas whose hybridised ethnic and/or national experience intersects with the experience of being a sexual minority. They all directly address this experience as a motivator to travel queerly or in queer places.

This article is a marked departure from the history of gay travel writing, which has been so dominated by white men. The discussion is also a deviation from existing debates in postcolonial travel writing, which have significantly underestimated the importance of sexuality as a criterion of difference, especially at the interface of histories of colonisation and globalisation. These departures, I argue, are not about telling a story about the emergence of a new genre or sub-genre: rather, they ask how contemporary travel writing can be understood as the layering of the three cartographies this article has touched on. This operation is less about the emergence of a sub-genre, and more about understanding patterns, movements, and histories which have always been there. The point of emergence is our awareness as scholars of the centrality of queerness to the representation of race in travel writing.

\section{Disclosure statement}

No potential conflict of interest was reported by the author.

\section{References}


Ahmed, Sara. 2004. The Cultural Politics of Emotion. Edinburgh: Edinburgh University Press.

Aizura, Aren Z. 2018. Mobile Subjects: Transnational Imaginaries of Gender Assignment. Durham: Duke University Press.

Aldrich, Robert. 2002. Colonialism and Homosexuality. London: Routledge.

Altman, Dennis. 2001. "Rupture or Continuity? The Internationalization of Gay Identities." In Post-colonial, queer, edited by John C. Hawley, 19-41. Albany: SUNY Press.

Altman, Derek and Jonathan Symons. 2016. Queer Wars. Cambridge: Polity Press.

Arondekar, Anjali and Geeta Patel. 2016a. “Area Impossible: Notes Towards an Introduction." GLQ 22 (2): 151-171.

Arondekar, Anjali. 2016b. “Thinking Sex with Geopolitics.” WSQ: Women's Studies Quarterly 44 (3): 332-335. Project MUSE, doi:10.1353/wsq.2016.0066.

Amor, Bani. 2017. "The Fragility of the Western Traveler.” Bitch Media, July 20.

Bacchetta, Paola. 1999. "When the (Hindu) Nation Exiles Its Queers.” Social Text 61, 141166. JSTOR, www.jstor.org/stable/488684.

Boone, Joseph Allen. 2015. The Homoerotics of Orientalism. New York: Columbia University Press.

Burton, Richard F. 1886. "Terminal Essay." In The Book of the Thousand Nights and a Night: a Plain and Literal Translation of the Arabian Nights Entertainments. London: Burton Club. Vol 10.

Butler, Judith. (1999) 2010. Gender Trouble. New York: Routledge. 
Butler, Judith. 2004. Precarious Life: The Powers of Mourning and Violence. London: Verso, 2004

Casey, Mark, and Thomas Thurnell-Read, eds. 2014. Men, Masculinities, Travel and Tourism. Basingstoke: Palgrave.

Chatterjee, Shraddha. 2018. Queer Politics in India: Towards Sexual Subaltern Subjects. Routledge.

Clark, Steve. 1999. "Introduction.” In Travel Writing and Empire: Postcolonial Theory in Transit, 1-28. London: Zed Books.

Clarke, Robert, ed. 2017. The Cambridge Companion to Postcolonial Travel Writing. Cambridge: Cambridge University Press.

Dasgupta, Rohit K. 2017. Digital Queer Cultures in India. London: Routledge.

Dave, Naisargi N. 2012. Queer Activism in India: A Story in the Anthropology of Ethics. Durham: Duke University Press.

Duggan, Lisa. 1994. "Queering the State.” Social Text 39, 1-14.

Edwards Justin D., and Rune Grauland, eds. 2012. Postcolonial Travel Writing. London: Palgrave.

El-Rouayheb, Khaled. 2005. Before Homosexuality in the Arab-Islamic Word, 1500-1800. Chicago: Chicago University Press.

Gopinath, Gayatri. 2005. Impossible Desires: Queer Diasporas and South Asian Popular Cultures. Durham: Duke University Press.

Greene, Graham. (1936) 2010. Journeys Without Maps. London: Penguin. 
Hamid, Mohsin. 2017. “"Travel Writing Dead?” Granta 138, 8 Feb. https://granta.com/istravel-writing-dead-hamid/

Haraway, Donna. 1991. Simians, Cyborgs and Women. New York: Routledge.

Hawley, John C., ed. 2001. Post-colonial, queer. Albany: SUNY Press.

Hendricks, Pepe. 2016. "Queer Muslim love: a time for ijtihad." Theology \& Sexuality 22 (12): 102-113. DOI: $\underline{10.1080 / 13558358.2017 .1296691 .}$

Holland, Patrick, and Graham Huggan. 2000. Tourists with Typewriters: Critical Reflections on Contemporary Travel Writing. Ann Abor: University of Michigan Press.

Iyer. Pico. 2017. “Is Travel Writing Dead?” Granta 138, 8 Feb. https://granta.com/is-travelwriting-dead-iyer/

Law, Benjamin. 2012. Gaysia: Adventures in the Queer East. Berkeley: Cleis Press.

Lewis, Reina. 2004. Rethinking Orientalism: Women, Travel and the Ottoman Harem. London: I.B. Tauris.

Luongo, M., ed. 2007. Gay Travels in the Muslim World. New York: Harrington Park Press, 2007.

Martel, Frédéric. 2018. Global Gay: How Gay Culture is Changing the World. Translated by Patsy Baudoin. Cambridge: MIT Press.

Massad, Joseph A. 2007. Desiring Arabs. Chicago: Chicago University Press.

McCormack, Donna. 2014. Queer Postcolonial Narratives and the Ethics of Witness. London: Bloomsbury.

McLean, Heather. 2018. "Regulating and Resisting Queer Creativity: Community Engaged Arts Practice in the Neo-liberal City.' Urban Studies 55 (16): 3563-3578 https://doi.org/10.1177/0042098018755066. 
Mahn, Churnjeet. 2015. “Travel Writing and Sexuality: Queering the Genre.” In The Routledge Companion to Travel Writing, edited by Carl Thompson, 46-56. Abingdon: Routledge.

Mitchell, Peta. 2008. Cartographic Strategies of Postmodernity. London: Routledge.

Miskdashi, Maya, and Jasbir K. Puar. 2016. "Queer Theory and Permanent War.” GLQ 2 (April): 215-222.

Padilla, Mark. 2008. Caribbean Pleasure Industry: Tourism, Sexuality, and AIDS in the Dominican Republic. Chicago: Chicago University Press.

Phillips, Richard. 1999. “Writing Travel and Mapping Sexuality: Richard Burton’s Sotadic Zone.” In Writes of Passage: Reading Travel Writing, edited by James Duncan and Derek Gregory, 70-91. London: Routledge.

Pratt, Mary Louise. 1992. Imperial Eyes: Travel Writing and Transculturation. Abingdon: Routledge.

Pritchard, Anne, Nigel Morgan, Diane Sedgley, and Andrew Jenkins. 2000. "Sexuality and Holiday Choices: Conversations with Gay and Lesbian Tourists." Leisure Studies 19 (2): 267-282.

Prosser, Jay. 1999. “Exceptional Locations: Transsexual Travelogues.” In Reclaiming Genders: Transsexual Grammars at the Fin de Siècle, edited by Kate More and Stephen Whittle, 83-114. London: Bloomsbury.

Rahman. Momin. 2010. “Queer as Intersectionality: Theorizing Gay Muslim Identities.” Sociology 4 (5): 944-961. 
Rault, Jasmine. 2017. "White Noise, White Affects: Filtering the Sameness of Queer Suffering." Feminist Media Studies 17 (4): 585-599.

Said, Edward W. 1978. Orientialism. London: Penguin.

Schulman, Sarah. 2012. Israel/Palestine and the Queer International. Durham: Duke University Press.

Siraj, Asifa. 2016. “Alternative realities: queer Muslims and the Qur'an.” Theology \& Sexuality 22 (1-2): 89-101.

Treat, John Whittier. 1999. Great Mirrors Shattered. Oxford: Oxford University Press.

Vanita, Ruth. 2002. Queering India: Same-Sex Love and Eroticism in Indian Culture and Society. London: Routledge.

Weeks, Jeffrey. 2007. The World we have Won: The Remaking of Erotic and Intimate Life. Abingdon: Routledge.

Williams, Loraine Erica. 2013. Sex Tourism in Bahia: Ambiguous Entanglements. Urbana: University of Illinois Press.

Woods, Gregory. 2015. “Gay Travel Writing: An Unstable Category?” In The Routledge Companion to Travel Writing, edited by Carl Thompson, 318-327. Abingdon: Routledge.

Woods, Gregory. 2016. Homintern: How Gay Culture Liberated the Modern World. New Haven: Yale University Press.

Yeğenğolu, Meyda. 1998. Colonial Fantasies: Towards a Feminist Reading of Orientalism. Cambridge: Cambridge University Press. 
Zanghellini, A. 2009. "Neither homophobic nor (hetero)sexually pure: contextualising

Islam's objections to same-sex sexuality." In Islam and Homosexuality, edited by Samar

Habib, 269-295. Santa Barbara, Denver and Oxford: Praeger.

\begin{abstract}
${ }^{1}$ While the authors referenced in this article deliberately work around and against the practices and markets of global LGBTQ tourism, their operations are important to the way discourses of "safety" and "desire" are constructed, as well as to those of gender, race and class. For more on this topic, see Pritchard, Morgan, Sedgley and Jackson (2000); Frohlick (2013); Casey and Thurnell-Read (2014); Padilla (2008), and Williams (2013). A recent media example of the intersection between LGBTQ tourism and debates about global queer rights is Vice's Gaycation which demonstrates how mainstream media representations of global queer life are focalised through the privileged experience of the mobile middle-class white tourist against the objectified black/brown/working-class queer body at risk from attack or discrimination (Rault 2017).
\end{abstract}

${ }^{2}$ Schulman's work draws on Judith Butler's work on witnessing as an ethical act (2004), and Donna Haraway's practice of "feminist positionality" (1991) which has become a foundational methodology for modern feminist criticism which emphasises that all knowledge is partial, contingent, and relies on the perspective/position of the viewer.

${ }^{3}$ John C. Hawley's edited collection Post-colonial, Queer (2001) is an important example of multidisciplinary approaches to a racialised understanding of who or what the "global gay" might be. For instance, Dennis Altman identifies the emergence of a "public homosexual world" (Altman 2001, 26) and the dominance of emotional, as well as sexual, relationships between (often) men as part of a differentiating discourse about "modern" gay or LGBTQ culture. Another important edited collection is Arnaldo Cruz-Malave and Martin F. Manalansan's Queer Globalizations: Citizenship and the Aftermath of Colonialism (2002). For a recent overview of the impact of the queer postcolonial in literary studies, see Donna McCormack's Queer Postcolonial Narratives and the Ethics of Witnessing (2014). Similar to these studies, "queer" in this discussion is an umbrella term used in a variety of senses: "To be queer is an identity; to live queer life is embodiment; to do queer things is action, doing something queerly/queering something are processes" (Chatterjee 2018). LGBTQ in this discussion will be used to describe specific historical and political movements, identities, and policies.

${ }^{4}$ Spatial metaphors have been at the centre of postcolonial studies of travel writing, especially in terms of thinking about the encounter with power and its potential disruption. Mary Louise Pratt's oft-quoted definition of the "contact zone" continues to provide the fundamental framework for describing the encounter between cultures. Contact zones are: "social spaces where disparate cultures meet, clash, and grapple with each other, often in highly asymmetrical relations of dominion and subordination - such as colonialism and slavery, or their aftermaths as they are lived out across the globe today" (Pratt 1992, 8). This model is a useful starting point, but is not sensitive to how sexuality and intimacy may have the capacity to work against the operation of particular asymmetries, as well as reproduce them. Pratt's work has been followed up by a body of postcolonial travel criticism which argues that, "postcolonial travel writing is not just oppositional or a 'writing back'; it offers frames of reference that exist outside the boundaries of European knowledge production" (Edwards and Grauland 2012, 3).

${ }^{5}$ While there have been major overviews of postcolonial travel writing including Edwards and Grauland (2012), and Clarke (2017), they have contained minimal accounts of queer life beyond highly influential individual figures such as Jan Morris. In studies of gay travel writing, including work by Gregory Woods (2015), there has been minimal attention to the intersection between race and sexuality. 


\footnotetext{
${ }^{6}$ Drawing on the work of Lauren Berlant and Judith Butler, Sara Ahmed's account of feeling as a queer practice has been important for making critical space for fleeting or tentative encounters with power: "This analysis of how we 'feel our way' approaches emotion as a form of cultural politics or world making" (Ahmed 2004, 12).

${ }^{7}$ For a recent reading of the digital and the queer postcolonial see Dasgupta (2017).

${ }^{8}$ For a more extensive discussion of Burton's Sotadic Zone in the context of travel writing, see Phillips (1999).

${ }^{9}$ This argument has been the basis of postcolonial critiques of the study of sexuality: "The study of the postcolonial nationalisms of the so-called Third World continues to be quasi-uniformly based on the presupposition of an unexamined totalizing signifier: universalized heterosexuality" (Bacchetta 1999, 141).

${ }^{10}$ These maps are recommended viewing by gov.uk for LGBTQ travellers and tourists abroad.

${ }^{11}$ For recent discussions of how Muslims' identities have been used as the queer's "hateful others", see Jin Haritaworn (2015). For a discussion of how Muslim religious identities have been viewed as incompatible with LGBTQ identities, see Rahman (2010), Hendricks (2016) and Siraj (2016).

${ }^{12}$ Gregory Woods's Homintern: How Gay Culture Liberated the Modern World (2016) and Frédéric Martel, Global Gay: How Gay Culture is Changing the World (2018) are recent examples of texts which directly engage with the growth of LGBTQ political and cultural movements with larger social and cultural transformations. A useful recent overview of how LGBTQ rights have been weaponised by the Global North, see Dennis Altman and Jonathan Symons, Queer Wars (2016).
} 